BIOKEMISTRI 18(1):45-51 (June 2006)

Available online at http://www.bioline.org. br/bk

and at http://www.aiol.info/journals/biokem

Printed in Nigeria

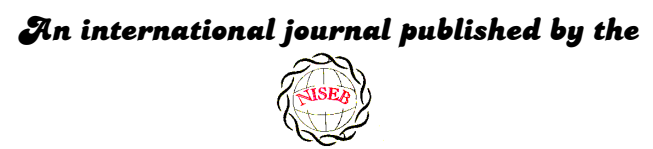

OVigerian \&ociety for \&̊xperimental \$iology

\title{
Pathogenicity and cell wall-degrading enzyme activities of some fungal isolates from cowpea (Vigna unguiculata [L] Walp)
}

\author{
Oluyemisi B. FAWOLE ${ }^{1}$, Oladimeji AHMED ${ }^{1}$ and Olusegun S. BALOGUN ${ }^{2 *}$ \\ Departments of ${ }^{1}$ Agronomy and ${ }^{2}$ Crop Protection, University of Ilorin, Ilorin Nigeria
}

Received December 17, 2005

MS/No BKM/2005/044, (C) 2006 Nigerian Society for Experimental Biology. All rights reserved.

\begin{abstract}
Nine fungal species isolated from cowpea seeds were used as inocula on four cowpea varieties commonly distributed to farmers in Ilorin, Kwara state, Nigeria by the National Seed Service, a subsidiary of the Federal Ministry of Agriculture and Natural Resources. The effects of fungi on germinability and seedling health were determined using seedling symptom test. Two of the virulent species were screened for the production of cell wall degrading enzymes using viscometric method. All the fungi reduced germination rate in all the cowpea varieties and different types of seedling symptoms were noted for the fungi. The symptoms included seed rot, chlorotic leaf development, stunted growth etc. Production of pectinases and cellulases by Aspergillus flavus and Penicillum sp. was observed and the virulence of the two organisms could be attributed to the activities of these cell wall degrading enzymes.
\end{abstract}

Keywords: Cowpea, Seed mycoflora, Aspergillus sp, Penicillium sp, Pectinases and Cellulases

*To whom correspondence should be addressed. Email:samcleo1 @yahoo.com, Tel: 0803-5814131 


\section{INTRODUCTION}

Cowpea, Vigna unguiculata (L) Walp (Fabaceae), has always been an important grain legume in tropical countries especially Nigeria and a veritable source of dietary protein for the teeming population of human and livestock ${ }^{1,2}$. The dry seed consists of about $25 \%$ protein and $67 \%$ carbohydrate ${ }^{3}$. In the 1970 's, about $94 \%$ of the total world crop was produced in Africa ${ }^{4}$. The situation remains much the same today but the optimization of production, which is still grossly at the subsistence level in this region continues to be hampered by pests ${ }^{5,6,7}$ and diseases $^{8,9}$. Some of the diseases of cowpea are known to be caused by seed-borne pathogens most of which are fungi $6,8,10,11$.

Many phytopathogenic fungi and bacteria have long been known to produce enzymes capable of hydrolyzing the polymeric carbohydrate constituent of higher plants cell wall. This factor might be responsible for the penetration of the fungi into the cowpea seeds ${ }^{12}$. In Nigeria, there is still a dearth of information on cowpea seed-borne fungi and their significance in disease development. Thus, the present study aimed at determining the pathogenicity of some cowpea seed-borne fungi and screening some of the virulent ones for their cell wall degrading enzyme activities.

\section{MATERIALS AND METHODS}

\section{Source of organisms}

Nine fungal species namely; Alternaria sp., Aspergillus flavus, Aspergillus niger, Cladosporium sp., Fusarium oxysporum, Fusarium semitectum, Fusarium solani, Fusarium sp. and Penicillum sp. isolated on Potato Dextrose Agar (PDA) by the standard procedure of culturing and subculturing, from cowpea seeds were used for the study. The cowpea seeds were obtained from the National Seed Service Ilorin, Kwara state, Nigeria and were stored under refrigeration $\left(4{ }^{\circ} \mathrm{C}\right)$ until needed for use.

\section{Preparation of inocula from the organisms} Spore suspension was prepared from highly sporulating organisms such as Aspergillus flavus, and Aspergillus niger by washing the spores from agar slants with sterile water. The number of spores was adjusted to $5 \times 10^{5}$ spores $/ \mathrm{ml}$ by dilution. Mycelia suspensions of other isolates were prepared by punching several small pieces from 10 day old cultures using $5 \mathrm{~mm}$ cork borer. The mycelia discs $(5 \mathrm{~mm})$ were comminuted in $150 \mathrm{ml}$ sterile water ${ }^{13}$ for 10 seconds in a blender.

\section{Inoculation of seeds}

To study the effect of seed borne fungi on germination and seedling growth, the method of Baggett and Fraizer ${ }^{14}$ in which seeds were coated with fungal cultures was adopted. Surface-sterilized seeds were mixed with the individual inocula in corked conical flasks for approximately one hour using mechanical shaker. After shaking, the seeds were left to stand in the inoculum for 8-10 hours. The seeds were then dried overnight on sterile paper towel.

\section{Effect of organisms on seed germination and seedling health}

Inoculated seeds were sown in small plastic pots filled with steam- sterilized soil. Sterile water was used for wetting the soil while being kept at room temperature for 6-10 days. The pots were later examined for germination and disease symptoms on emerging seedlings.

\section{Cell wall degrading enzymes assay}

Two demonstrably virulent fungal isolates of the nine isolates were selected for the assay of cell wall degrading enzyme enzyme activities. The selected organisms were prepared on PDA slants for 3 days at $28 \pm 2{ }^{\circ} \mathrm{C}$. The cultures were then separately washed with sterile water to dislodge the spores and the resulting spore suspension was used for preparing enzyme filtrate.

\section{Preparation of enzyme}

Seeds of cowpea cultivar (ITA 90-22-2K) susceptible to attack by the virulent fungi were ground in a blender. The ground seeds were sterilized in an autoclave at $15 \mathrm{lb}$ pressure for 15 minutes to get rid of all seed-borne fungi and other contaminants. Two separate $50 \mathrm{~g}$ of the sterile ground seeds was moistened with $50 \mathrm{ml}$ of each inoculum separately and the mixture incubated for 3-5 days at about $28 \pm 2^{\circ} \mathrm{C}$. Sterile water $(150 \mathrm{ml})$ was later added in each case and the mixture agitated for 30 minutes with 
mechanical shaker. The resulting mixture was filtered using sterile Whatman No. 1 filter paper. The filtrates were kept under refrigeration until needed.

\section{Enzyme assay}

Viscometric method was used in measuring the activity of the enzymes. Viscosity was determined using the method of Endo ${ }^{15}$. The reaction mixture contained $15 \mathrm{ml}$ of carboxymethyl cellulose (CMC) $(1 \% \mathrm{w} / \mathrm{v})$ in citrate phosphate buffer ( $\mathrm{pH} 5.5$ ) and $15 \mathrm{ml}$ of enzyme filtrate for cellulose assay. For pectinase assay, the mixture contained $15 \mathrm{ml}$ pectin $(2 \%$ $\mathrm{w} / \mathrm{v})$ in citrate phosphate buffer $(\mathrm{pH} 5.5)$ and $5 \mathrm{ml}$ of the enzyme filtrate. Measurements were made in glass viscometer after the mixtures have been incubated for 2 hours at $30^{\circ} \mathrm{C}$. The enzymatic activities were expressed in terms of percentage viscosity change. The reducing rate of viscosity was calculated from the following equation:

$$
\mathrm{A}=\frac{\mathrm{Vo}_{\mathrm{O}}-\mathrm{Vt}_{\mathrm{t}}}{\mathrm{V}_{\mathrm{o}}-\mathrm{Vs}_{\mathrm{s}}} \times 100
$$

Where, $\mathrm{Vo}_{\mathrm{O}}=$ flow time in seconds of pectin/cellulose + inactivated enzyme. $\mathrm{Vt}=$ flow time in seconds of pectin/cellulose + active enzyme. Vs = flow time in seconds of solvent (water) + inactive enzyme. One unit of viscosity reducing activity (VRU) is defined as the quantity of enzyme necessary for $50 \%$ viscosity change of $20 \mathrm{ml}$ of the reaction mixture at $30^{\circ} \mathrm{C}$.

Data collected from repeated experiments were pooled and analyzed for variance at 5\% level of significance.

\section{RESULTS AND DISCUSSION}

\section{Pathogenic effects of seed mycoflora}

All the fungi tested reduced percentage seed germination and average height of seedling of the four cowpea varieties compared with the control as shown in Figures 1 and 2.

Among seed borne organisms, fungi cause maximum seed damage, which include reduced germination and vigour ${ }^{16}$. Reduced germinability of seeds may be attributed to damaged embryos from deep seated infection of seeds. All the fungi used in this study induced disease symptoms on germinating seedlings. The symptoms observed ranged from chlorosis to necrotic spots development on the leaves stems and roots while the control remained healthy (Plate 1).

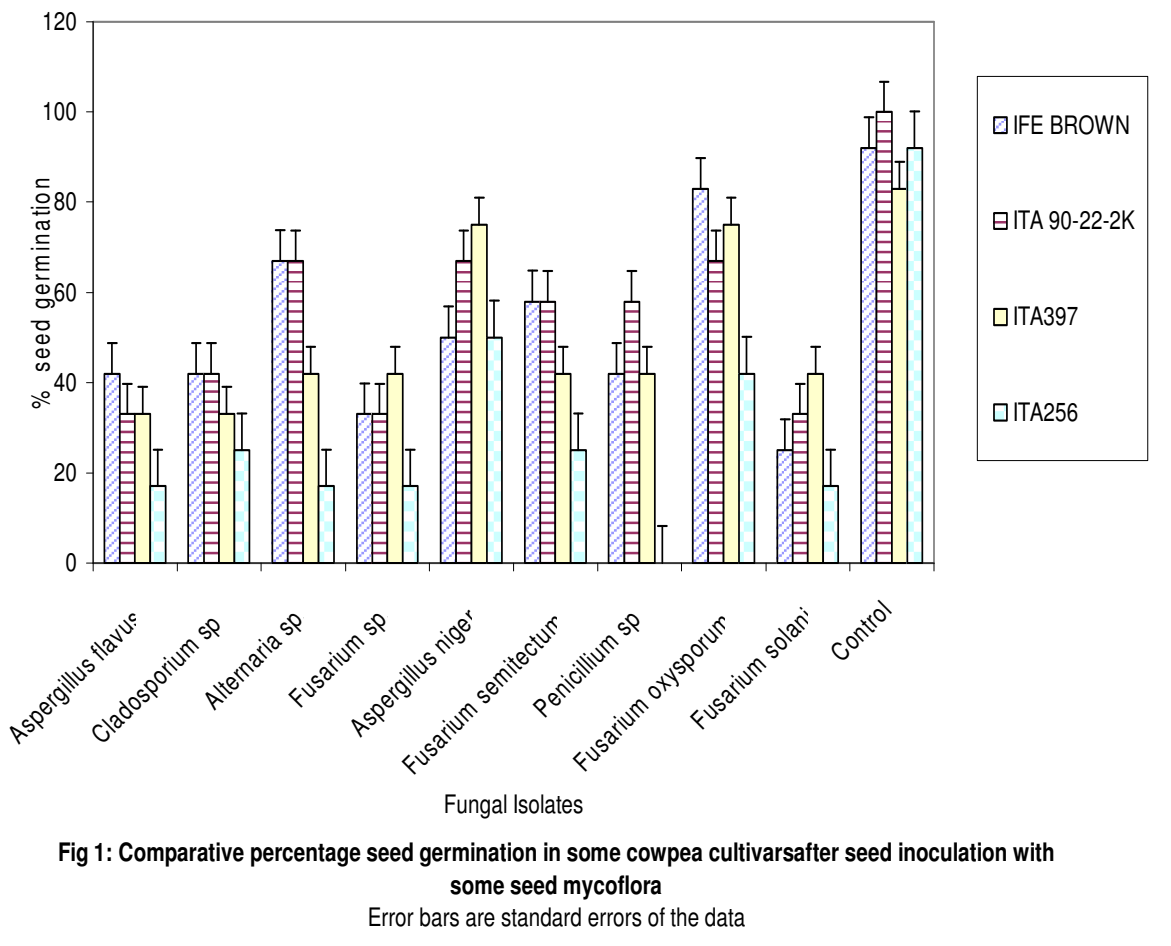




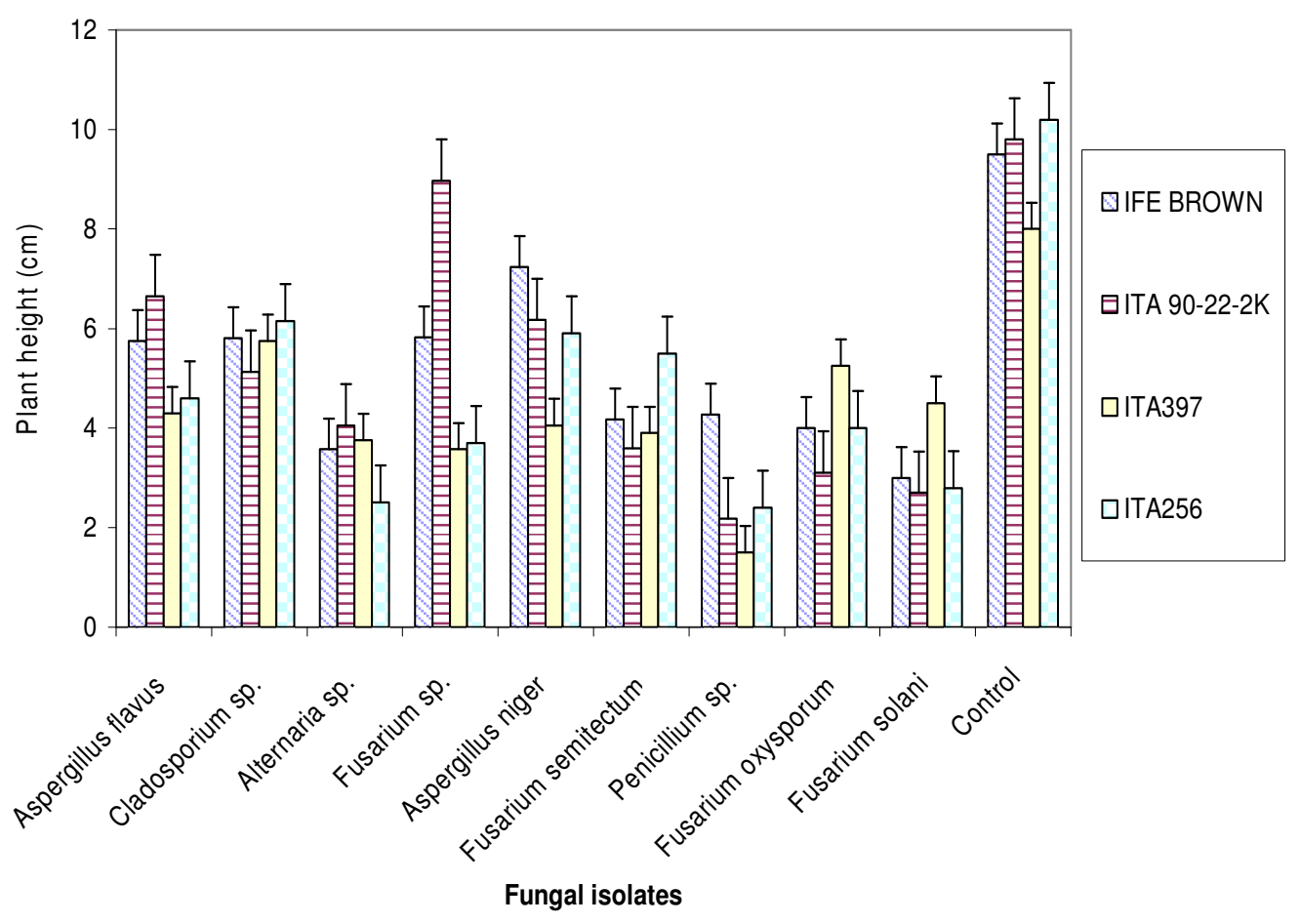

Fig 2: Comparative effect of seed inoculation with some fungal isolates on mean height of cowpea seedlings

Error bars are standard errors of the data

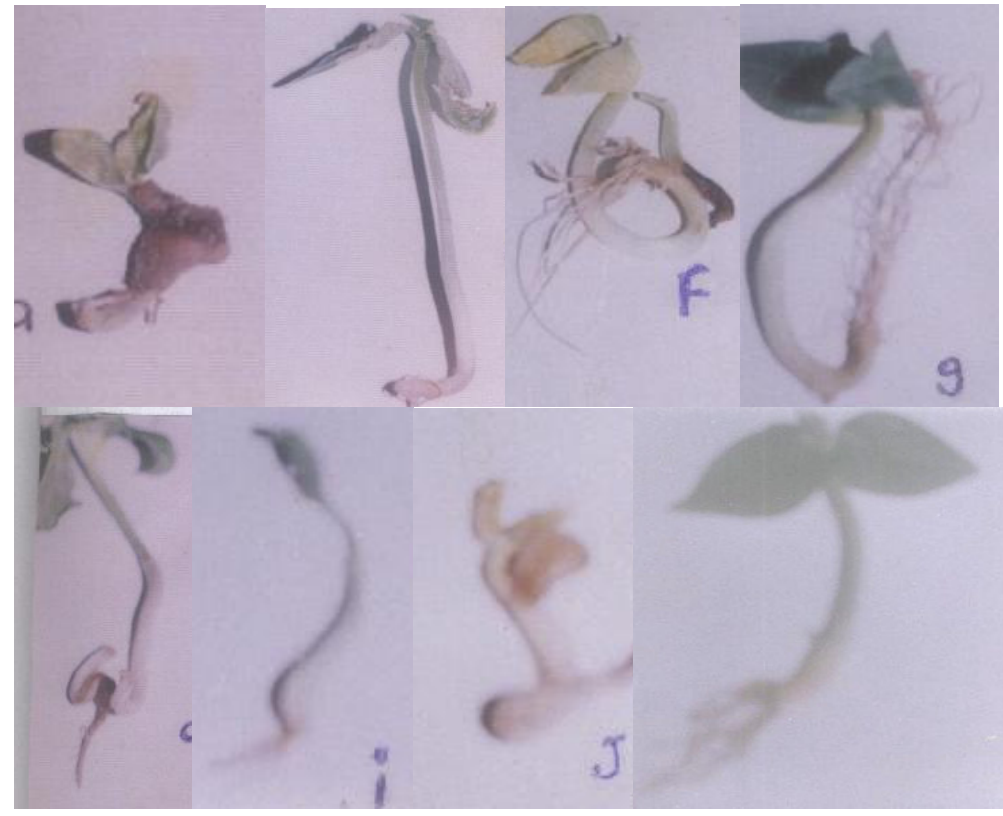

Plate 1: Manifestation of different disease symptoms in germinating cowpea seedlings after infection of the seeds with selected fungal isolates from cowpea seeds.

Top Row from left: Aspergillus flavus, Cladosporium sp, Alternaria sp. and Penicillium sp.

Bottom Row from left: Fusarium semitectum, F. oxysporium, F. solani and Sterile Distilled water only (Control). 
The impact of fungal inocula on germinating seeds and seedling health which includes seed rot, stunted seedlings and yellowing of leaves is outlined on Table 1 .

Many seed borne fungi on cowpea in India have been reported to reduce seed germination and produce symptoms on infected seedlings ${ }^{17}$. It was further observed ${ }^{17}$ that fungi such as Aspergillus flavus and Fusarium solani were associated with damage to plumule, radicle and hypocotyl of germinating seedlings. This kind of observation explains the reducing effects of such fungi, which were also used in this study on seedling development.

\section{Cell wall degrading enzyme activities of some test fungi}

The results of the assay for pectolytic and cellulolytic enzyme production by two of the virulent fungi (Aspergillus flavus and Penicillium $s p$ ) are presented in Table 2. A significantly $(\mathrm{P} \leq 0.05)$ higher volume of enzyme preparation from A. flavus than that of Penicillium $s p$ was required to bring about $50 \%$ viscosity changes in carboxymethyl cellulose (CMC) indicating a higher cellulase activity in the preparation from Penicillium sp. Conversely, pectinase activitiy of enzyme preparation from A. flavus was significantly higher than that of Penicillium sp. Nowithstanding the difference in quantities, the ability of these moulds to produce cellulases and pectinases explains their virulence. The cell wall-degrading enzymes must have facilitated the penetration of the fungi and hence their ability to cause deep seated infection of the seeds and consequent symptom manifestation in the seedlings.

Table 1: Pathogenic effect of fungal isolates on cowpea seedlings

\begin{tabular}{|c|c|c|c|c|}
\hline $\begin{array}{l}\text { FUNGAL } \\
\text { TREATMENT }\end{array}$ & IFE BROWN & ITA 90-22-2K & ITA 397 & ITA 256 \\
\hline $\begin{array}{l}\text { Aspergillus } \\
\text { flavus }\end{array}$ & $\begin{array}{l}\text { Weak seedling } \\
\text { with decayed } \\
\text { root and yellowing } \\
\text { of first leaves }\end{array}$ & $\begin{array}{l}\text { Root rot and } \\
\text { necrotic spots } \\
\text { on leaves }\end{array}$ & $\begin{array}{l}\text { Cotyledons } \\
\text { wilt quickly } \\
\text { with signs of } \\
\text { green spores }\end{array}$ & Seed rot \\
\hline $\begin{array}{l}\text { Cladosporium } \\
\text { sp. }\end{array}$ & $\begin{array}{l}\text { Decay of root and } \\
\text { development of } \\
\text { wrinkled leaves }\end{array}$ & Yellowing of leaves & $\begin{array}{l}\text { Loss of first } \\
\text { leaves by } \\
\text { seedling }\end{array}$ & $\begin{array}{l}\text { Decay of root } \\
\text { system }\end{array}$ \\
\hline Alternaria sp. & $\begin{array}{l}\text { Death of leaves and } \\
\text { chlorosis }\end{array}$ & $\begin{array}{l}\text { Seed rot decay of root and } \\
\text { yellowing of leaves }\end{array}$ & Root decay & Seed rot \\
\hline Fusarium sp. & Leaves become wrinkled & Damaged root & $\begin{array}{l}\text { Seed rot and } \\
\text { weak seedlings }\end{array}$ & $\begin{array}{l}\text { Seed rot and } \\
\text { weak seedling }\end{array}$ \\
\hline $\begin{array}{l}\text { Aspergillus } \\
\text { niger }\end{array}$ & Seedlings are weakened & $\begin{array}{l}\text { Appearance of brown lesion } \\
\text { on roots, first leaves and } \\
\text { generally weak seedlings }\end{array}$ & $\begin{array}{l}\text { Seed rot and } \\
\text { weak seedlings }\end{array}$ & $\begin{array}{l}\text { Seed rot and } \\
\text { weak seedling }\end{array}$ \\
\hline $\begin{array}{l}\text { Fusarium } \\
\text { semitectum }\end{array}$ & $\begin{array}{l}\text { Seed rot, unhealthy } \\
\text { seedlings with damaged } \\
\text { roots and chlorotic leaves }\end{array}$ & $\begin{array}{l}\text { Dropping of first leaves and } \\
\text { stunted seedlings }\end{array}$ & $\begin{array}{l}\text { Seed rot and } \\
\text { weak seedlings }\end{array}$ & $\begin{array}{l}\text { Seed rot and } \\
\text { stunted } \\
\text { seedlings }\end{array}$ \\
\hline Penicillium sp. & $\begin{array}{l}\text { Seed rot and damaged } \\
\text { roots }\end{array}$ & $\begin{array}{l}\text { Stunted seedling wilt } \\
\text { damaged roots and wrinkled } \\
\text { leaves }\end{array}$ & $\begin{array}{l}\text { Seed rot and } \\
\text { weak seedlings }\end{array}$ & Seed rot \\
\hline $\begin{array}{l}\text { Fusarium } \\
\text { oxysporum }\end{array}$ & $\begin{array}{l}\text { Seed rot and stunted } \\
\text { growth }\end{array}$ & $\begin{array}{l}\text { Seed rot, stunted seedling } \\
\text { loss of first leaves }\end{array}$ & $\begin{array}{l}\text { Seed rot and } \\
\text { appearance of } \\
\text { brown lesion on } \\
\text { roots }\end{array}$ & $\begin{array}{l}\text { Seed rot, root } \\
\text { damage and } \\
\text { stunted } \\
\text { seedling }\end{array}$ \\
\hline $\begin{array}{l}\text { Fusarium } \\
\text { solani }\end{array}$ & $\begin{array}{l}\text { Seed rot and } \\
\text { Stunted seedlings }\end{array}$ & $\begin{array}{l}\text { Seed rot, damage to roots, } \\
\text { dark spots on cotyledons }\end{array}$ & $\begin{array}{l}\text { Stunted seedlings } \\
\text { and seed rot }\end{array}$ & Seed rot \\
\hline $\begin{array}{l}\text { Control (No } \\
\text { fungi) }\end{array}$ & Healthy seedlings & Healthy seedlings & Healthy seedlings & $\begin{array}{l}\text { Healthy } \\
\text { seedlings }\end{array}$ \\
\hline
\end{tabular}


Table 2: Pectolytic and cellulolytic activities of enzyme preparations from Aspergillus flavus and Penicillium sp

\begin{tabular}{llc}
\hline Fungal Isolate & \multicolumn{2}{c}{ Enzyme activity (VRU) (ml) } \\
\cline { 2 - 3 } & Cellulase & Pectinase \\
\hline Aspergillus flavus & $91.20 \pm 2.02 \mathrm{~b}$ & $39.02 \pm 1.10 \mathrm{a}$ \\
Penicillium sp & $80.23 \pm 2.13 \mathrm{a}$ & $51.50 \pm 1.22 \mathrm{~b}$ \\
\hline $\begin{array}{l}\text { V.R.U (Viscosity Reducing Unit) is defined as quantity of enzyme necessary for } 50 \% \text { viscosity change of } 20 \mathrm{ml} \text { of } \\
\text { the reaction mixture at } 30^{\circ} \mathrm{C} . \text { Means } \pm \text { std. dev. followed by different letter in a column are significantly different } \\
\text { at } P<0.05 .\end{array}$
\end{tabular}

In general, the seeds of all the four varieties of cowpea used for this study were to varying extent susceptible to fungal infections and they exhibited the ability to carry over such infections to the seedling stage. The observations made in this study have further underscored the need for regular seed testing and seed treatments with effective protective and systemic fungicidal preparations, by the seed services, before disbursement to growers.

\section{REFERENCES}

1. Labeyrie, V. (1981) Vainere la carence proteique par le developpement des legumineuses alimentaires et la protection de leurs recoltes contre le bruchides. Food and Nutrition Bulletin 3: 24-38.

2. Murdock, L.L., R.E Shade, L.W. Kitch, G. Ntoukam, J.E. Lowenberg-Deboer, J.E. Huesing, W. Moar, O.L. Chambliss, C. Endondo and J.L. Wolfson (1997) Post harvest storage of cowpea in sub Saharan Africa. In: Singh, B.B., D.R. Mohanraj, K.E. Dashiel, L.E.N. Jackai (eds): Advances in Cowpea Research, pp 302-312. IITA/JIRCAS Publication, IITA, Ibadan, Nigeria.

3. Onioume, I.C. (1978) Crop Science, $21^{\text {st }}$ Edition. Cassell: Tropical Agricultural Series 56. 4. F.A.O. (1973) Production Year Book. FAO, Rome.

5. Adedire, C.O. and O.E. Ajayi (2003) Potential of sandbox, Hura crepitans L. seed oil for protection of cowpea seeds from Callosobruchus maculatus Fabricius (Coleoptera: Bruchidae) infestation. Journal of Plant Diseases and Protection 110: 602-610.
6. Allen, D.J and Emechebe, A.M (1981) Identification of resistance in cowpea (Vigna unguiculata) to disease of the African Savanna. Tropical Agriculture 58: 267-274.

7. Singh, S.R, Jackai, L.E.N, JHR dos Santos and Adalla, C.B (1990) Insect pests of cowpea. In; Insect pests of tropical food legumes edited by S.R Singh, John Wiley and Sons Chichester U.K Pages 43-89.

8. Emechebe, A.M. (1980) Scab disease of Cowpea (Vigna unguiculata) caused by a specie of the fungus Sphaceloma. Annals of Applied Biology 96: 11-16.

9. Thottapilly, C., Rossel, H.W and Singh, B.B (1988) Virus diseases of cowpea in Nigeria and development of multiple virus resistant cowpea lines. Page 383 in Proceedings $5^{\text {th }}$ International Congress of Plant Pathology. 20-27 August 1988, Kyoto Japan.

10. Emechebe, A.M and Shoyinka, S.A. (1985) Fungal and Bacterial diseases of Cowpea in Africa. In: Cowpea Research, Production and Utilization edited by S.R Singh and K.O Rachie. John Wiley and Sons Chichester U.K. pp 173192.

11. Kalshrestha, D.D; Mathur, S.B and Neergaard, P. (1976) Identification of seedborne species of Colletotrichum. Friesia 11:116-125.

12. Wolfgang, D.; Barer, D.; Bateman, D.F.; Catherine, H. and Whalen, H. (1977) Purification of an Endo $\beta, 1-4$ galactanase produced by Sclerotiorum: Effect on isolated plant cell walls and potato tissues. Plant Pathology 67: 862-868. 
13. Pratt, R.G (1982) A new vascular wilt disease in crimson clover by Fusarium oxysporum. Phytopathology 72: 622-627.

14. Baggett, J.R and Fraizer, N.A. (1973) Seasonal pattern of Fusarium root rot development in resistant vs succeptible cultivars of Phaseolus vulgaris L. Horticultural Science 8: $214-216$

15. Endo, A. (1961) Studies on pectolytic enzymes of molds Part II: On the pectolytic activities of several molds. Agric. Biol. Chem. 25: 389-393.

16. Shetty, H.S. (1990) Different types of damages in seeds caused by seed borne fungi. In: Seed Pathology. Edited by Mathur S.B. and Johs Jǿrgensen. Technical Center for Agricultural and Rural Cooperation. Danish Government Institute of Seed Pathology for Developing Countries.

17. Saad, S., Raghunathan, A.N. and Shetty, H.S. (1988) Seed mycoflora of Cowpea (Vigna unguiculata (L) Walp) and their pathogenic importance. Seed Sci Technol. 16: 541-548. 